\title{
ПРАГМАТИКА СТРАХУ В УКРАЇНСЬКІЙ ФРАЗЕМІЦІ
}

\author{
ЖАННА КРАСНОБАСВА-ЧОРНА \\ Донецький національний університет, Вінниця - Україна \\ prikladnik1@mail.ru
}

\section{PRAGMATYKA STRACHU W UKRAIŃSKICH FRAZEOLOGIZMACH}

\author{
ŻANNA KRASNOBAJEWA-CZORNA \\ Doniecki Uniwersytet Narodowy, Winnica — Ukraina
}

STRESZCZENIE. W przedstawionym artykule strach został sklasyfikowany jako ograniczenie wolności stanowiącej jedno z głównych pojęć wartościowego obrazu świata dla Ukraińca. Do opisu strachu zastosowano metodę analizy parametrycznej semantycznej struktury frazemu z. aktualizacją makrokomponentu oceniającego, jak również metodę pól tematycznych. Strach w języku ukraińskim zaprezentowany został w opozycji aksjologicznej "wolność psychologiczna — przejaw strachu" wartości ogólnoludzkiej "wolność". Ponadto wyróżniono szesnaście grup semantycznych z pojęciem strachu.

\section{PRAGMATICS OF FEAR IN UKRAINIAN PHRASEMICS}

\author{
ZHANNA KRASNOBAIEVA-CHORNA \\ Donetsk National University, Vinnytsia - Ukraine
}

\begin{abstract}
Fear is positioned in the article as a limitation of freedom - a base fragment of the axiological worldview of the Ukrainian. Description of fear is implemented with the help of the method of parametric analysis of the phraseme's semantic structure with accentuation of the appraisive macro-component and the method of thematic fields. Fear in Ukrainian Studies presents the phrasemic axiological opposition of "psychological freedom - manifestation of fear" of the universal human value of "freedom" and is formed in sixteen semantic subgroups.
\end{abstract}

\footnotetext{
7 сихологію страху презентовано кількома важливими напрямами студіювань: поведінкові основи страху та біхевіористський підхід (Г. Айзек, Дж. Уотсон, Ч. Спілбергер); вивчення невротичного страху (тривоги) та психоаналітична традиція (З. Фрейд, К. Хорні, К. Юнг); пошук смислу страху як ознаки людського буття з акцентуванням його позитивності (С. Кьєркегор, Р. Мей, М. Гайдеггер); визнання страху негативним феноменом, що заважає самоактуалізації особистості (А. Маслоу, К. Роджерс); психіатрична специфіка страху (Б. Карвасарський, Г. Ушаков) тощо. Згідно з філософською інтерпретацією страх виникає внаслідок безсилля духу (Б. Спіноза).

Страх кваліфікуємо як істотне обмеження свободи людини: він паралізує людину, заважає рухатися вперед, утримує від учинення важливих дій і не дає насолоджуватися життям, що визначає необхідність свободи від страху. Актуальність статті зумовлена відсутністю в україністиці праць, присвячених аналізу страху, позиціонованого як обмеження свободи - базового фрагменту ціннісної картини світу — на фраземному рівні.
} 
Мета статті полягає у визначенні конститутивних ознак, структурної та прагматичної специфіки страху в українській фраземіці як репрезентанта цінності “свобода”. Фактичний матеріал почерпнуто з авторитетного фраземографічного видання Словник фразеологізмів української мови ${ }^{\prime}$.

Д. Фішер ${ }^{2}$, С. Рубінштейн ${ }^{3}$ та інші психологи інтерпретують страх як короткочасну емоцію або стійке відчуття, породжувані в людини реальною / ірреальною небезпекою. Формами вияву страху є тривожні та болісні переживання, переляк, жах, паніка, а також стихійні або свідомі дії, спрямовані на самозбереження.

Страх є найбільш небезпечною з усіх емоцій. І. Павлов розглядає страх як вияв природного рефлексу, пасивно-захисну реакцію з легким гальмуванням кори великих півкуль. Страх заснований на інстинкті самозбереження, має захисний характер і супроводжуваний певними змінами вищої нервової діяльності, відбивається на частоті пульсу та диханні, показниках артеріального тиску, виділенні шлункового соку тощо. На думку С. Ільїна ${ }^{4}$, страх корисний для людини-біологічної істоти, проте шкідливий для людини-соціальної істоти, оскільки стає перешкодою для досягнення поставлених цілей. Емоція страху виникає як відповідь на дію загрозливого стимулу. О. Захаров ${ }^{5}$ уважає, що універсальний і одночасно фатальний характер мають дві загрози - смерть і крах життєвих цінностей, які протистоять життю, здоров'ю, самоствердженню, особистому та соціальному добробуту. Страх, на думку К. Ізарда ${ }^{6}, \epsilon$ сильним душевним хвилюванням, викликаним несподіваною небезпекою, тривожним передчуттям, очікуванням і т. ін. Його породжують також конкретні причини, що так чи так пов'язані з теорією цінностей і нецінностей (війна, розорення, зрада, голод, хвороба тощо), тривогою, що живе в душі людини. 3. Фрейд7 визначає страх як стан афекту, поєднання певних відчуттів ряду “задоволення — незадоволення” та їхнього сприйняття. У науковій літературі розрізняють раціональний страх, зумовлений зовнішніми чинниками, і страх глибинний, ірраціональний.

Специфічною постає і векторність страху: страх виникає не після фіксагії майбутнього зла, а разом з ним, страх є вбачанням страпного. Об'єкт страху обов' язково наділений загрозою, що не зменшує страху, а формує його.

Страх має здатність виступати як стійка ознака свідомості не тільки окремої особистості, а й соціальної групи й суспільства загалом. Соціалізація почуття страху відбувається по-різному в різних умовах мікро- та макросередовища, реалізуючись через сором'язливість, боязкість, ступор, пригноблення, безправ'я, відчуження тощо.

Лінгвістичні візії страху презентовані працями Л. Вороніна ${ }^{8}$, Н. Кирилової $^{9}$, Н. Терещенко ${ }^{10}$ та ін. Страх постає предметом численних фраземних сту-

${ }^{1}$ Словник фразеологізмів украйнськой мови, укладачі: В. М. Білоноженко, І. С. Гнатюк, В. В. Дятчук, Н. М. Неровня, Т. О. Федоренко, Київ 2003.

2 Д. Ф. Фишер, Страх, [в:] Психологическая энциклопедия, под ред. Р. Корсини, А. Ауэрбаха, СПб. 2003.

${ }^{3}$ С. Л. Рубинш тейн, Основы общей психологии, СПб. 2002, с. 624-638.

${ }^{4}$ Е. П. Иль и н, Эмочиии и чувства, СПб. 2001, с. 39.

${ }^{5}$ А. И. З ахаров, Дневные и ночные страхи у детей, СПб. 2000 , с. 7.

${ }^{6}$ К. Э. Изард, Психология эмочий, СПб. 1999, с. 292-293.

7 3. Фр ейд, Введение в психоанализ: Лекиии, Москва 1989, с. 250-263.

8 Л. В. В ор он и н, Конщепт "страх" в русском и немецком языках (контрастивный анализ на материале произведений М. Булгакова, К. Тухольского и их переводов на английский), автореф. дисс. канд. филол. наук, Москва 2005.

${ }_{9}^{9}$ Н. В. К и р и л л о в а, Концептуализация эмоции страха в разноструктурных языках (на материале русского, английского и чуваиского языков), автореф. дисс. канд. филол. наук, Чебоксары 2007.

${ }_{10}^{10}$ Н. В. Тсрсщснко, Эвфемистические средства объективачии конщепта "страх" (на материале русского и английского языков), автореф. дисс. канд. филол. наук, Пятигорск 2005. 
діювань (див. праці А. Булатової ${ }^{11}$, О. Бутенко ${ }^{12}$, Д. Добровольського ${ }^{13}$, С. Зайкіної $^{14}$ та ін.).

Аналіз комплексної вербалізації страху в художній комунікації засвідчує, на думку Н. Кирилової, що страх переживається разом з такими почуттями та станами: “агресивними” емоціями (лють, гнів, обурення), ненавистю, огидою, недоброзичливістю, безпорадністю, тугою та смутком, болем, соромом, розгубленістю, надією, радістю та щастям, повагою, інтересом, подивом, любов'ю. Семантичними ознаками страху, на думку авторки, постають: негативний емоційний стан, сильна тривога, реальна небезпека, уявна небезпека, душевне сум'яття - у російській і неприємний емоційний стан, болючість емоційного стану, близькість небезпеки, можливість небезпеки, очікування небезпеки, психосоматичні зміни - в англійській мовах.

Під час дослідження поняття страх у німецькій і російській лінгвокультурах О. Бутенко доповнює метод концептуального аналізу герменевтикоінтерпретаційним, що дає ій змогу у фраземіці та пареміології виділити ноеми “емоційний і фізичний стан людини”, “інтенсивність переживання”, “могутність, сила страху", "спосіб уникнення переживання страху", "психічна дієвість страху", "перебільшення значимості страху", "практична недоцільність переживання", “практична доцільність страху", "страх - смерть”, “страх Божого покарання", “страх невдачі", “страх - ті, хто стоїть вище (ієрархія)”, “одиниця вартості”, “страх - боягузтво”, “відсутність страху" (німецька мова) і ноеми "емоційний і фізичний стан людини"; "психічна дієвість страху"; "інтенсивність переживання"; "страх - смерть"; "страх - доля, Бог”; "регулятор учинків людей”; “практична недоцільність страху”; “усвідомленість страху”; “перебільшення значимості страху"; “подолати страх допомагають усвідомлення підтримки з боку інших, активні дії”; “страх - боягузтво"; "сміливість, мужність як здатність подолати страх“" (російська мова).

Д. Добровольський виділяє чотири області джерел ідіом із семантикою страху в російській і німецькій мовах: 1) холод (рос. Страх леденит кровь; кровь стынет / леденеет в жилах; зубы стучат / зуб на зуб не попадает от страха; дрожать как осиновый лист; нім. Zittern wie Espenlaub; mit Zittern und Zagen; jmdm. Stehen die Haare zu Berge; kalte Fufie haben / bekommen / kriegen); 2) діарея (рос. Полные штаны (от страха); наложить в итаны (от страха); медвежья болезиь; нім. Aftersausen haben; die Hosen (gestrichen) voll haben; sich in die Hosen machen / scheissen (vor jmdm. Oder etw.); Schiss haben / kriegen; Mujfensausen haben); 3) фізична слабкість (рос. Коленки дрожат / трясутся / подгибаются; поджсилки трясутся (от страха); прошиб холодный пот (от страха); не мочь даже пальием пошевелить от страха; нім. Jmdm. Bleibt das Herz stehen; nicht atmen konnen vor Angst; Blut (und Wasser) schwitzen); 4) ворожа істота (рос. Страх дуиит; страх охватывает / сковывает / парализует; страх пронизывает ч.-л. душу; нім. Jmdn wtirgt die Angst; jmdm. Sitzt die Angst im Nacken). Дослідник зазначає, що не враховує одиничних образів (наир.: рос. Бо-

${ }^{11}$ А. М. Булатова, Лексико-фразеологические средства репрезентаиии эмоиионального кониепта страх в немеиком и русском языках, автореф. дисс канд. филол. наук, Казань 2015.

${ }^{12}$ Е. Ю. Бу те пा ко, Копцептуализачия попятия "страх" в пемеикой и русской липгвокульmурах, автореф. дисс. канд. филол. наук, Тверь 2006.

13 Д. О. До бро в оль с к и й, Семантика идиом как переводческая проблема, [в:] Перевод и лингвистика текста, Москва 1994, с. 96-104.

${ }^{14}$ С. В. 3 а йк и н а, Эмочиональный концепт "страх" в английской и русской лингвокультуpax (сопоставительный аспекm), автореф. дисс. канд. филол. наук, Волгоград 2004. 
яться как черт ладана або нім. Lampenfieber haben), і зауважує, що такий поділ $\epsilon$ умовним, оскільки наявні ідіоми, які можна одночасно зарахувати до кількох груп (напр.: рос. Прошиб холодный пот або нім. Kalte Ftifie haben належать до категорій “Холод” і “Фізична слабкість”).

С. Зайкіна вважає, що фраземологізація емоційного концепту "страх" / "fear" відбувається на основі метафоричних і символічних образів, які апелюють до психосоматичних і фізіологічних симптомів переживання емоції страху. Найбільш актуальними для англійської мовної свідомості $€$ семантичні ознаки “тремор", “зниження температури”, в основі яких лежать однойменні фізіологічні вияви емоції страху. Для російської мовної свідомості пріоритетними ознаками виступають “вираз очей” "тимчасова нездатність бачити, дихати, говорити”, тобто переживання страху спричиняє більш серйозні наслідки.

Опис страху в українській фраземіці здійснено за допомогою методу параметричного аналізу семантичної структури фраземи з акцентуалізацією оцінного макрокомпонента та методу тематичних полів, тобто через фраземосемантичні поля - фраземосемантичні групи - фраземосемантичні підгрупи (далі ФСПГ), де фраземосемантичним полем постає цінність, у межах проблематики статті - цінність “свобода", фраземосемантичною групою - елемент фраземної аксіологічної опозиції, а ФСПГ — сукупність фразем, об'єднаних диференційною семою, що пов'язує їх опозитивними відношеннями схожості або протиставлення. Страх презентує фраземну аксіологічну опозицію "психологічна свобода - вияв страху" загальнолюдської цінності "свобода" та формується шістнадцятьма ФСПГ: “Боятися, побоюватися" і "Не боятися", “Відчувати страх" і “Опам'ятатися, заспокоїтися, отямитися від страху"; "Виявляти занепокоєння, тривожитися, хвилюватися" і “Заспокоїтися, відчути полегшення, спокій, перестати тривожитися, хвилюватися", “Перебувати в стані тривоги, занепокоєння, дуже хвилюватися, переживати” і “Заспокоюватися, долати вияв почуттів, емоційне піднесення, переживання", “Викликати хвилювання, тривожити” i “Заспокоювати, розраювати, тіпиити”, “Бути в небезпегі”, "Наражатися на небезпеку”, "Сповіщати про небезпеку, подавати сигнал тривоги" i “Бути в безпеці”, “Сміливий (хоробрий, небоязкий)" i “Несміливий (лякливий, боязкий)”.

У фраземіці страх фіксується ФСПГ "Боятися, побоюватися" (обминати (обходити, оббігати і т. ін.) десятою дорогою (вулицею) (3); як (мов, ніби і т. ін.) опечений (рідше обпечений) (1); труса празнувати, жарт.). Відчуття страху і супровідних із ним явищ неприємності, неспокою, моторошності передає ФСПГ "Відчувати страх": [аж] мороз іде (проходить, пробігає і т. ін.) / niшов (пройщов, пробіг і т. ін.) поза шкірою (поза спиною, по спині і т. ін.) (2); мороз поза (за) спиною (за плечима, поза шкірою і т. ін.) ходить (бігас і т. ін.) (2); мороз із-за плечей бере (2); мороз хапає / вхопив за плечі (2); [аж] мураики бігають (пробігають, лізуть і т. ін.) / побігли (пробігли, забігали, полізли і т. ін.) по спині (по тілу, за плечима і т. ін.) (2); аж око в'яне; острах бере (обіймас, охоплюе і т. ін.) / узяв (обійняв, охопив і т. ін.); [аж (i)] очі на лоб (на лоб, рідше догори і т. ін.) лізуть / полізли (3); [і (аж)] в (на) дущі (на сериі, у грудях, у п'ятах і т. ін.) похололо (похолонуло); [аж] холоне / захололо (захолонуло, похолонуло) серие (в сериі); [аж] холоне / захолола (захолонула, похолонула) дуиа (2); серце стигне (холоне) / прохололо (охололо) (2)); кров холоне (крижсаніс, застигас) / захолола (застигла) у жилах.

За матеріалами художньої літератури страх, що репрезентований фраземами, викликають: 
- $\quad$ війна: I от пройшла війна. Страшна. Грізна. Згадати, і то мороз поза шкірою... (В. Собко); Коли ці сталеві громади [танки] з'явились зі степу перед лінією укріплень, не одному з бійців мурашки пробізли по тілу (О. Гончар); А Клава он прийхала, таке розказус, щңо душа холоне!.. - Вона стала розповідати, як бомбили їх у дорозі (О. Гончар);

- смерть: При одній думиі про те, що на його ииї може зненацька затягнутися зашморг, по спині Паршецького пробігають мураики (М. Тарновський); У грудях Зіньки похололо. Їй здалось, щзо збитий з ніг чоловік уже мертвий (А. Шиян);

- погляд: Витріщила на мене очі, аж мене мороз вхопив за плечі (М. Коцюбинський); Юрко глянув на сестру такими очима, щзо в неї мурашва побігла спиною (М. Томчаній); Тут Денис так глянув на Трохима, щзо у того жсжски задрижали, і у душі похолонуло (Г. Квітка-Основ'яненко);

- місцевість: Навколо якісь кущі, хащі і холод могильний, аж мороз поза икурою ходить (Гр. Тютюнник); Коли Маруся підходила до цьього місия, йй стало моторошно, по тілу забігали мурашки (Ф. Бурлака);

- темнота: Темінь дихнула глибоко, безнадійно. Порожнеча стисла серие, аж мурашки побізли по спині (Ю. Мушкетик); I от знову увижасться мені страмна темнота... Тихо... Глухо... страмно, ажс в серці холоне (Панас Мирний);

- висота: Гляпув з високості вниз, і голова йому пішла обертом, а по тілу пробігли мураики. Він схопився за граніт (П. Панч);

- сон: Спав тривожно. Від жахливих кочмарів, загадкових снів він раптом прокидався, весь облитий холодним потом (Ю. Збанацький);

- слова: Як сказала вона це - в мене в душі похололо (І. Нечуй-Левицький);

- прокльони: Горпина, слухаючи прокльони дідові, обмирала з страху (Панас Мирний);

- звуки: виття вовків (Вовки витягали соло, аж око в'януло (І. Франко)); шелест, стук (Я прислухавсь. Наймениий иелест або стук - і моє серце падає (М. Коцюбинський)); кроки (Нi, Сашко, мені здалося, що хтось тихенько, нишком пройшов на горищі недалеко від нас. В мене знову по спині сипнули мурашки (Л. Смілянський)); крик (У Грицька морозом сипнуло від того Христиного крику (Панас Мирний)); сміх (Недокус посміхався, а в мене морозом сипнуло поза шкірою (Ю. Збанацький)) і регіт (У Христі аж у душі похолонуло від того реготу. Вона зразу догадалася, що Оришка тільки замина правду (Панас Мирний));

- $\quad$ людина: Він не пам'ятає, як відчинив двері. Назустріч холодне, незнайоме обличчя чужої жінки. ... Серце обірвалося (О. Донченко);

- звістка: [Герасим:] Думав, що довідалась за громі, аж всередині похолонуло (I. Карпенко-Карий) тощо.

Виявами страху постають такі дії:

- завмирати, ціненіти: мороз пробігае / пробіг; обмирати / обмерти зі страху; серие падає (обривається) / виало (обірвалося);

- остовпіти: як (мов, наче і т. ін.) громом прибитий (рідше приглушений);

- відчувати сильне серцебиття: серие як (ледве, мало, трохи і т. ін.) не вискочить [з грудей];

- відчувати холод (переважно неприємне відчуття): мороз по шкірі продирає; [аж] снігом сипле за шкуру; [аж] морозом сипнуло (сипонуло) [за (поза) спиною (икірою), по спині]; 
- відчувати сильний озноб: холод пробирас (проймас) / пробрав (пройняв) [аж] [оо кісток];

- відчувати жар в усьому тілі: як (мов, ніби і т. ін.) скупали в окропі (1);

- хвилюватися: обливатися / облитися холодним потом;

- у утрачати спокій, холоднокровність, рівновагу: пускатися / пуститися беpera (2);

- $\quad$ тремтіти: цокотіти (цокотати, цокати) зубами.

У фраземіці страх набуває ознаки 'раптовий': серие мре (завмирає, замира) / завмерло (замерло). Страждальний характер страху передають фраземи перетліти на вугіль (на попіл) (1); серие переболіло (перегоріло, перекипіло і т. ін.); душа переболіла (перегоріла, перекипіла і т. ін.); душа перетліла (перемліла) з актуалізацією сем 'намучитися', 'знемогтися', 'настраждатися' (від тяжких думок, неспокою, хвилювань, тривоги, страху, туги). Маніпулювання страхом зафіксовано фраземою наганяти (нагонити) / нагнати холоду.

Спрямованість страху на майбутнє (сема 'в передчутті чогось невідомого, неприємного') підтверджують численні контексти 3 художньої літератури: Холодним потом обливалась Малайка, вся терта і гострим оком вдивлялась y пітьму, паче питала, як буде? (М. Коцюбинський); Калинович стояв, обливаючись холодним потом, і ждав, щзо буде дачі (I. Франко); - Василю, не дуже мені подобаються ті твої нічні мандри. Як подумаю, щзо з тобою може щось статись, то аэс шкіра терпне на мені (Ірина Вільде).

Інтенсифікацію страху передають фраземи боятися своєї (власної) тіні; [i] духу боятися, семи 'сильний' (серце опинилося в n'ятах; не чути (не відчувати) землі [під собою (під ногами)]) і 'великий' ([аж] шкура (икіра) терпне).

Позбавлення відчуття страху інтерпретується як психологічна свобода, супроводжувана полегшенням. У фраземіці психологічну свободу передає ФСПГ “Опам'ятатися, заспокоїтися, отямитися від страху” (прийти / приходити в себе (2)). Відсутність страху презентована ФСПГ "Не боятися” (глянути / әлядіти страхові (небезпеці) у вічі; [i] море по коліна (рідше по коліно) (1)).

Відчуття загрози або відсутність почуття безпеки викликають хвилювання та занепокоєння, що постають спільним емоційним компонентом для страху та тривоги. О. Захаров ${ }^{15}$ витлумачує страх як емоційно загострене відображення у свідомості людини конкретної загрози для життя та добробуту; а тривогу - як емоційно загострене відчуття майбутньої загрози. Тривога, на відміну від страху, не завжди почуття, що сприймається негативно, оскільки вона можлива й як радісне хвилювання, очікування (напр., завмирати / завмерти серцем (душею) із значенням 'дуже хвилюватися, переживати (з переляку, від захоплення, тривоги і т. ін.'). Об’єднувальним моментом страху й тривоги є почуття занепокоєння. Разом з тим, страх можна розглядати як вираження тривоги в конкретній, об'єктивованій формі, якщо почуття не пропорційні небезпеці, й тривога набуває затяжного характеру, напр.: як (мов, немов і т. ін.) по линвi; висіти дамокловим мечем; не мати спокою; сидіти болячкою на серці; сидіти в душі; як (мов, неначе і т. ін.) у лихоманиі (із активізацісю сем 'постійно', 'невідступно'). Тривога, передчуття загрози, небезпеки, неприємних подій передається фраземами як (мов, ніби і т. ін.) на вулкані; як на чеку; з важким (нелегким) серцем.

Тривога у фраземіці презентована:

a) ФСПГ “Виявляти занепокоєння, тривожитися, хвилюватися” (бити / забити тривогу (2); бити / ударити на сполох (2); скніти душею (2));

\footnotetext{
${ }^{15}$ А. И. З ахаро в, Указ. источник, с. 10-11.
} 
б) ФСПГ "Перебувати в стані тривоги, занепокоєння, дуже хвилюватися, переживати" (душа (серце) не на місці; коти шкребуть на сериз; мати страх [на душі]; [як (мов, ніби і т. ін.)] на ножах (2); n’явки (n'явка) ссуть (ссе) за серцүе (під серием); тенькнуло / тенькає в серці (в грудях); щемить на дуиі);

в) ФСПГ “Викликати хвилювання, тривожити” (кидати / кинути жарину в серие (в груди); різати око (очі) (3)).

Стан тривоги може виражатися поглядом (водити очима (2)) і супроводжуватися:

- $\quad$ роздумами (думки (гадки) беруть (обсідають) / взяли (обсіли); думки (гадки, думи) снуються в голові);

- болем (доходити / дійти до серия (до душі) — 'боляче вражати'; боліти душею; серце болить / заболіло (зболіло, наболіло); душа болить (зболіла) 'уболівати');

- стомою від журби, туги (нудити / занудити (білим) світом (2));

- неспокоєм (серце стискається (стискується) / стислося (стиснулося));

- нудьгою (де (куди) дівати / діти (подіти) себе);

- зворушенням (брати /взяти за дуиу (за серце));

- поганим, гнітючим настроєм (на серuі [наче] миші шкребуть (икрябають, скребуть і т. ін.) / зашкребли (зашкрябали, заскребли і т. ін.));

Тривога може зумовлюватися соромом і ганьбою (як (мов, наче і т. ін.) живцем пектися на рожні), дріб'язковими, не вартими уваги питаннями (буря у склянці води).

Інтенсифікація тривоги передається фраземами зачіпати / зачепити за живе (2); серие тенькає / тенькнуло; ссати серце (душу) ('дуже тривожити / тривожитися'); крик (лемент) душі ('крайній вияв тривоги, душевного болю'); повертати / повернути душу ('глибоко тривожити').

Однією з основних причин страху та тривоги постає небезпека, відображена у фраземіці ФСПГ “Бути в небезпеці” (висіти (повисати) / повиснути на волосинцуі (на волоску, на волосині) (2); на волосинцуі (на волосині) (1); вскочити 6 зашморг; під ударом); ФСПГ "Наражатися на небезпеку” (лізти (грубо перти, пертися і т. ін.) / полізти на рожен (проти рожна) (1); лізти чортові на роги (в зуби), фам.; випробовувати долю); ФСПГ “Сповіщати про небезпеку, подавати сигнал тривоги” (бити / забити тривогу (1); бити / ударити на сполох (1); на твалт (1)).

У фраземіці зафіксовані ситуації, коли:

- $\quad$ є загроза небезпеки (сидіти на пороховій бочц̧і (на пороховому погребі);

- $\quad$ небезпека або неприємність загрожує з обох боків (між двох вогнів);

- $\quad$ причиною загрози є власна вина (встромити голову в петлю (2));

- небезпеки уникають або удають, ніби ії немає (ховати голову в пісок);

- $\quad$ знаходять спосіб уникнути небезпеки (в одне (одно) вухо влізти, а в друге вилізти);

- небезиекою нехтують (як віл на рогатину, зневажл. Із семами 'внерто' та 'настирливо').

Урятуватися від небезпеки можна втечею: винести / виносити ноги. Ситуацію безпеки передає ФСПГ “Бути в безпеці”: вскочити і вискочити; у надійних руках (1).

Спокій у фраземіці представлено:

а) ФСПГ “Заспокоїтися, відчути полегшення, спокій, перестати тривожитися, хвилюватися" (відлягло (відійшло) від серияя (від душі, на серціі, на душі); 
душа стала на місце; відпочивати / відпочити (спочити) серцем (душею); камінь з дуиі (з грудей) спав (звалився, упав і т. ін.); прийти / приходити до пам'яті (до тями, до тямку і т. ін.) (1));

б) ФСПГ “Заспокоюватися, долати вияв почуттів, емоційне піднесення, переживання” (брати / взяти себе в руки (2); опановувати / опанувати себе (рідко собою); піджимати (підгортати, підгинати і т. ін.) / піджати (підгорнути, підігнути, підібгати і т. ін.) хвіст (хвоста) (2));

в) ФСПГ “Заспокоювати, розраювати, тішити”: відводити / відвести дуиу (2); гріти серце (дуиу). Інструментом заспокоєння постають співчуття та ласка (вidiгрівати / відігріти серце (душу)), сподівання (тішити себе надією (думкою, мрі$\epsilon ю$ і т. ін.)), маркером спокою виступає повернення радості (обсушити (обтерти, осуиити і т. ін.) [гіркі (гарячі)] сльози (рідше очі)). Моральне полегшення передають фраземи дякувати Богові (Богу, Господові, Господеві); хвалити Бога (1).

За умови втрати людиною контролю над собою та виконання вчинків, що суперечать вимогам моралі, через страх, вона оцінюється суспільством як боягузлива. I навпаки, подолання людиною почуття страху характеризується як сміливість, мужність, що відображено у фраземі, порівн.: ФСПГ “Сміливий (хоробрий, небоязкий)" (не [3] полохливого (лякливого, боязкого і т. ін.) десятка (роду); не з полохливих (полохких); не з заячого пуху) і ФСПГ "Несміливий (лякливий, боязкий)" (не з хороброго десятка; страшків син, перев. ірон.). Сміливість у фраземіці супроводжується ознаками 'незалежний' ([i] чортові не брат), 'відважний’ ([сам (i)] чорт не брат), 'принциповий’ (душа (2уба) не з лопуцька), сміливі, рішучі дії (випростувати (розправляти) / випростати (розправити) плечі) — семами 'відчайдушно' (на ходу підметки рвати (зривати)), 'виявити сміливість, кмітливість, спритність' (впіймати (піймати, спіймати, вхопити) вовка за вухо (за вуха)). Несміливість поєднувана з ознаками 'сором'язливий' і 'нерішучий' (як (мов, ніби і т. ін.) засватаний); 'делікатний', 'нерішучий' i 'ненаполегливий’ (розводити / розвести розводи). Виявом боягузтва є втеча: показувати / показати спину (потилицю)) (1).

Отже, страх презентує фраземну аксіологічну опозицію “психологічна свобода - вияв страху” загальнолюдської цінності “свобода” та формується шістнадцятьма семантичними підгрупами. Оцінне значення фразем із семантикою страху формують здебільшого: 1) наявність у складі фраземи слова з негативною оцінкою (болячка, лихоманка, тривога, сполох, лвалт, чорт і т. ін.); 2) емоційна асоціація, пов'язана $з$ конкретним компонентом фраземи (зоонімом (коти, миші, п'явки, віл, засцьь), соматизмом (спина, плечі, голова, око, лоб, ухо, серце, груди, n'яти, жили, ноги, руки, зуби, роги, хвіст)), або ситуацією, що покладена в основу фраземи (встромити голову в петлю (2)). До складу прагматичної лексики потрапляють також лексеми холод, мороз, вугілля, вогонь, попіл, вулкан, порох, ніж, рогатина; 3 ) наявність конотативних маркерів, зафіксованих у фраземографічному джерелі (семи 'фамільярне', 'зневажливе' тощо).

Застосована методика дала змогу також установити, що в українській фраземіці: 1) страх має вектор у майбутнє; 2) складниками страху виступають побоювання, боязкість, тривога, небезпека; 3) якісно-кількісними ознаками страху постають 'сильний' i 'великий', 'глибокий', 'раптовий’, ‘тривалий', 'постійний’, 'невідступний’; 4) страх супроводжуваний муками, стражданнями, моторошністю, неприємними відчуттями, тобто має яскраво виражену негативну оцінку; 5) виявами страху є ціпеніння, тремтіння, сильне серцебиття, відчуття холоду, сильного ознобу, жару в усьому тілі; 6) позбавлення відчуття страху інтерпретується як психологічна свобода. 